\section{Use of Phenol in determining Chromatographic Purity}

WATER-SATURATed phenol is a well-known solvent for the paper chromatographic separation of polyphenols and was, for example, one of the solvents used by Roberts and Wood ${ }^{1}$ for the two-dimensional paper chromatographic separation of tea-leaf polyphenols. This solvent was, however, later discarded in favour of water ${ }^{2}$, or preferably 2 per cent acetic acid ${ }^{3}$.

The use of 75 per cent (w/v) aqueous phenol (or $m$-cresol saturated with water) has proved to be of inestimable value in determining the chromatographic purity of various flavonoid compounds isolated in this laboratory. A fraction isolated from rooibos tea (Aspalathus acuminatus) and suspected of consisting solely of isoquercitrin was found by chromatography in phenol to consist of two major flavonoid components even though the material was chromatographically homogeneous in $n$-butanol/acetic acid/ water $(4: 1: 2 \cdot 2 \mathrm{v} / \mathrm{v})$, in water, in 15 per cent acetic acid, in ethyl acetate saturated with water, in propan$2-o l /$ water $(1: 3.5 \mathrm{v} / \mathrm{v})$, and in chloroform/butan-2.ol/ water $(2: 4: 4 \mathrm{v} / \mathrm{v})$. Separation also took place in 60 per cent acetic acid but was incomplete and not very convincing. The identity of the second component is still under investigation.

In the isolation of quercetin-4'-monoglucoside from the inner scales of the onion (Allium cepa $\mathrm{L}$. $)^{4}$, difficulty was found in reproducing the melting point of the crystalline material obtained on successive recrystallizations from various solvents. The material was chromatographically homogeneous in all the more commonly employed solvent systems, only phenol and $m$-cresol resolving it completely into two components. The material was therefore purified by chromatography on Whatman $3 M M$ paper sheets with 75 per cent $(w / v)$ aqueous phenol as the developing solvent. The contaminant, which had a higher $R_{F}$ in phenol than quercetin-4'-monoglucoside, crystallized from aqueous ethanol as fine yellow needles with melting point $259-261^{\circ}$.

Dopartment of Food Science,

\section{B. H. KofpPEN}

University of Stellenbosch, South Africa.

${ }^{3}$ K.oberts, E. A. H., and Wood, D. J., Biochem. J., 49, 414 (1951).

${ }^{2}$ Roberts, E. A. H., and Wood, D. J., Biochem. J., 49, xxxiii (1951).

${ }^{3}$ Cartwright, R. A., and Roberts, E. A. H., Chem. and Indust., 1389 (1954).

- Koeppen, B. H., and Van der Spuy, J. E., S. Afr. J. Agric. Sci. (in the press).

\section{Trypsin Inhibitor in Wholewheat Flour}

Preciminary work on a trypsin inhibitor in wholewheat flour was reported by Shyamalar. A crude concentrate containing the trypsin inhibitor was prepared by the 'ammonium sulphate' method of Borchers et al. ${ }^{2}$ modified by Lyman ${ }^{3}$ as follows:

(I) A homogenate of the wholewheat flour was prepared by mixing the flour with ten volumes of water in a blender. The $p H$ was adjusted to $4 \cdot 2$ with acid and the mixture was allowed to stand overnight.

(2) The 'ammonium sulphate precipitate' was obtained by adding ammonium sulphate, 30 per cent of the volume of the extract. The precipitate containing the inhibitor was re-precipitated with ammonium sulphate. The material obtained was dialysed overnight and then lyophilized. Approximately $3 \mathrm{gm}$. of material was obtained from $300 \mathrm{gm}$. of flour.

The activity of trypsin was determined by the method of Anson ${ }^{4}$ using the modification of Orringer et al. ${ }^{5}$. The degree of colour produced by the phenol reagent indicated the relative proteolytic activity of the trypsin. For testing the activity of the inhibitor, it was added to the enzyme at several concentrations and the degree of proteolytic activity inhibited was estimated. A logarithmic plot of this inhibition gave a straight line from which the point of 50 per cent inhibition could be readily obtained.

Crude material (6.5 mgm.) prepared as described here was needed for 50 per cent inhibition of the activity of trypsin while $55 \gamma$ of a crude concentrate of soybean trypsin inhibitor prepared by the same method was needed for 50 per cent inhibition. The activity was lost when the preparation was heated in a boiling water bath for $20 \mathrm{~min}$. Table 1. TRXPSIN-INHIBITING AOTIVITY OF THE INHIBITORS FROM

\begin{tabular}{|c|c|c|c|c|c|}
\hline \multicolumn{4}{|c|}{ Ammonium sulphate precipitation } & \multicolumn{2}{|c|}{ Trichloroacetic acld } \\
\hline $\begin{array}{l}\text { ybean } \\
\text { hibitor } \\
(\gamma)\end{array}$ & $\begin{array}{l}\text { Optical } \\
\text { density } \\
\text { at } 765 \mu\end{array}$ & $\begin{array}{l}\text { Wholewheat } \\
\text { inhibitor } \\
\text { (mgm.) }\end{array}$ & $\begin{array}{l}\text { Optical } \\
\text { density } \\
\text { at } 765 \mu\end{array}$ & $\begin{array}{c}\text { Wholewheat } \\
\text { inhibitor } \\
\text { (mgm.) }\end{array}$ & $\begin{array}{l}\text { Optical } \\
\text { density at } \\
\quad 765 \mu\end{array}$ \\
\hline $\begin{array}{r}0 \\
13 \\
26 \\
52 \\
78\end{array}$ & $\begin{array}{l}0.480 \\
0.412 \\
0.355 \\
0.270 \\
0.180\end{array}$ & $\begin{array}{r}2 \cdot 5 \\
5 \cdot 0 \\
10 \cdot 0\end{array}$ & $\begin{array}{l}0 \cdot 375 \\
0 \cdot 285 \\
0 \cdot 170\end{array}$ & $\begin{array}{l}0 \\
1 \cdot 0 \\
2 \cdot 0 \\
3 \cdot 0 \\
5 \cdot 0\end{array}$ & $\begin{array}{l}0.480 \\
0.395 \\
0.320 \\
0.270 \\
0.172\end{array}$ \\
\hline ger & inhib & $\begin{array}{l}50 \text { per cent } \\
\text { at } 6.5\end{array}$ & hibition & $\begin{array}{r}50 \text { per cen } \\
3.5\end{array}$ & lbition at \\
\hline
\end{tabular}

The crude concentrate prepared as described was used as the starting material for the extraction of the inhibitor with trichloroacetic acid by the method of Kalser and Grossman ${ }^{6}$. The inhibitor appeared in the trichloroacetic acid filtrate while the precipitate had no inhibitor in detectable amounts. The trichloroacetic acid filtrate was dialysed and lyophilized. $3.5 \mathrm{mgm}$. of this material was needed for 50 per cent inhibition. The appearance of the inhibitor in the trichloroacetic acid filtrate indicates a possible similarity in its behaviour to the pancreatic juic $\theta$ trypsin inhibitor. Further attempts to purify the material are under way.

Recently, Learmonth and Wood ${ }^{7}$ reported the presence of a trypsin inhibitor in wheat flour using different assaying techniques.

\section{G. Shyamala \\ Barbara M. KenNedy \\ R. L. LYMAN}

Department of Nutrition

and Home Economics,

University of California, Berkeley, 4.

'Shyamala, G., Biologisal Evaluation of Protein Quality of Chapatis, Master's thesis, University of California, Berkeley (1960).

${ }^{2}$ Borchers, R., Ackerson, C. W., and Mussehl, F. E., Arch. Biochem., 19, 317 (1948).

3 Lyman, R. L., and Wilcox, S. S., J. Nutr., 72, 265 (1960).

4 Anson, M. L. J. Gen. Physiol., 22, 79 (1938).

Orringer, D., Lauber, F. U., and Hollander, F., Seience, 111, 88 (1950).

Kalser, M. H., and Grossman, M. I., Qastroenterology, 29, 35 (1955).

${ }^{7}$ Learmonth, E. M., and Wood, J. C., Chem. and Indust., 51, 1569 (1960).

\section{PHYSIOLOGY}

\section{Prevention of Freezing Damage to Living Cells by Pyridine $\mathrm{N}$-Oxide}

Pyridine, like dimethyl sulphide, forms a highboiling, water-soluble oxide, pyridine $N$-oxide (PNO). It was surmisod that PNO might protect living cells against freezing damage in the same way as dimethyl sulphoxide $e^{x}$ and some other aliphatic compounds ${ }^{2}$. The particular interest attached to $P N O$ is that it would be the first aromatic compound to be used in this connexion. 